\title{
Lead poisoning in cattle and chickens in the state of Pará, Brazil ${ }^{1}$
}

\author{
José Diomedes Barbosa ${ }^{2 *}$, Henrique dos Anjos Bomjardim², Karinny Ferreira \\ Campos $^{2}$, Marcos Dutra Duarte², Pedro Soares Bezerra Júnior ${ }^{2}$, Aldo Gava ${ }^{3}$, \\ Felipe Masiero Salvarani ${ }^{2}$ and Carlos Magno Chaves Oliveira ${ }^{2}$
}

\begin{abstract}
Barbosa J.D., Bomjardim H.A., Campos K.F., Duarte M.D., Bezerra Júnior P.S., Gava A., Salvarani F.M. \& Oliveira C.M.C. 2014. Lead poisoning in cattle and chickens in the state of Pará, Brazil. Pesquisa Veterinária Brasileira 34(11):1077-1080. Instituto de Medicina Veterinária, Universidade Federal do Pará, Campus Castanhal, Rodovia BR-316 Km 61, Saudade, Castanhal, PA 68740-970, Brazil. E-mail: diomedes@ufpa.br

The present study describes the occurrence of lead poisoning in cattle and chickens in Pará, Brazil. In a lot composed of 80 calves from a dairy herd, 10 animals became sick and nine died, but one animal recovered after being removed from the paddock. Upon inspection of this paddock, the presence of truck batteries used to store energy captured by solar panels was found. The clinical signs observed in calves included difficult breathing, nasal discharge, excessive salivation, corneal opacity, pushing of the head against objects and recumbency. The chickens had decreased oviposition and produced eggs with thin or malformed shells. The necropsy findings of the cattle, as well as the histopathological changes observed, were of little significance except for one animal that showed mild astrocytosis histopathology in the cerebral cortex. In one of the chickens, renal histopathology showed mild multifocal acute tubular necrosis. The mean lead concentrations in the livers and kidneys of the cattle were $93.91 \mathrm{mg} / \mathrm{kg}$ and $209.76 \mathrm{mg} / \mathrm{kg}$, respectively, and the mean concentration detected in chicken livers was $105.02 \mathrm{mg} / \mathrm{kg}$. It was concluded that the source of lead poisoning in these calves and chickens were the truck battery plates, which were within reach of the animals.
\end{abstract}

INDEX TERMS: Lead poisoning, neurological disease, solar energy, cattle, poultry.

RESUMO.- [Intoxicação por chumbo em bovinos e galinhas no estado do Pará.] 0 presente estudo descreve a ocorrência de intoxicação por chumbo em bovinos e galinhas no Pará, Brasil. Em um lote composto de 80 bezerros de um rebanho leiteiro, 10 animais ficaram doentes e nove morreram, e um animal se recuperou após ser removido do piquete. Após a inspeção deste piquete, foi observada a presença de baterias de caminhões usados para armazenar a energia captada por painéis solares. Os sinais clínicos observados nos bezerros incluíam dificuldade respiratória, corrimento nasal, salivação excessiva, opacidade da córnea, pressão da cabeça contra objetos e decúbito. As galinhas

\footnotetext{
${ }^{1}$ Received on September 26, 2014.

Accepted for publication on October 10, 2014.

2 Instituto de Medicina Veterinária, Universidade Federal do Pará (UFPA), Campus Castanhal, Rua Maximino Porpino da Silva 1000, Castanhal, PA 68740-080, Brazil. *Corresponding author: diomedes@ufpa.br

${ }^{3}$ Laboratório de Patologia Animal, Centro de Ciências Agroveterinárias (CAV), Universidade de Desenvolvimento de Santa Catarina (UDESC), Av. Luiz de Camões 2090, Lages, SC 88520-000, Brazil.
}

tinham diminuída oviposição e os ovos produzidos eram com cascas malformadas ou tinham a casca mais fina. Os achados de necropsia e as alterações histopatológicas observadas nos bovinos eram de pouco significado, com exceção de um animal que mostrou leve astrocitose no córtex cerebral. Em uma das galinhas, na histopatologia renal observou-se leve necrose tubular aguda multifocal. As concentrações de chumbo médios nos fígados e rins dos bovinos eram $93,91 \mathrm{mg} / \mathrm{kg}$ e $209,76 \mathrm{mg} / \mathrm{kg}$, respectivamente, e a concentração média no fígado de galinhas foi $105,02 \mathrm{mg} /$ kg. Concluiu-se que a fonte de contaminação por chumbo nesses bezerros e galinhas eram placas de bateria de caminhão, aos quais os animais tiveram acesso na pastagem.

TERMOS DE INDEXAÇÃO: Intoxicação por chumbo, doença neurológica, energia solar, bovinos, aves.

\section{INTRODUCTION}

Lead is a metal used for the manufacturing of paints, batteries, greases and oils for car engines, farm machinery and 
pipes. Its importance as a toxic metal and environmental pollutant is gaining greater importance and represents a danger to both human and animal health. When lead-containing products are left in pastures or places that animals have access to, such as in waste sites, they can be accidentally consumed and cause intoxication (Traverso et al. 2004). Lead poisoning in animals occurs primarily via the oral route, through the ingestion of lead-containing products and the ingestion of pastures and water contaminated by lead (Oskarsson et al. 1992). In addition to these pathways, lead poisoning occurs less commonly by the airways due to the prolonged inhalation of lead fumes and by absorption of the metal through the skin (Lemos et al. 2004).

Among the animal species susceptible to lead poisoning, cattle are the main subjects of lead intoxication (Traverso et al. 2004, Guagnini et al. 2005, Marçal 2005); however, sheep (Liu 2003), goats (Gava 2001), horses (Palacios et al. 2002), birds (Mazliah et al. 1989) and small animals (Morgan 1994) may also experience lead intoxication. In Brazil, there have been several reported cases of lead poisoning in cattle in the state of Paraná, in dairy cows from farms neighboring a metal factory (Marçal 2005); in the state of Rio Grande do Sul, in animals kept in pastures contaminated by spilled contents of paint cans and in animals grazing in military artillery training fields (Traverso et al. 2004, Guagnini et al. 2005); in the state of Mato Grosso do Sul, in Nellore cattle kept in pastures near a car battery recycling facility (Lemos et al. 2004); and in horses in the Vale da Paraíba, São Paulo state, on a farm close to an industrial lead processing and recovery facility (Mazzeo et al. 1984).

To date, there have been no reports of lead poisoning in animals in the state of Pará. Therefore, the present study sought to report the occurrence of lead poisoning in cattle and chickens on a farm in the city of Bom Jesus do Tocantins, Pará.

\section{MATERIALS AND METHODS}

Epidemiological, clinical and pathological data were obtained during visits to farms where calves presented abnormal clinical neurological signs followed by death. Five sick animals were subjected to clinical examination, following the methods of Dirksen et al. (1993), and necropsy was performed in four calves and two chickens. Samples of brain, spinal cord, heart, lung, spleen, liver, kidney, intestine and lymph nodes were collected and fixed in $10 \%$ formalin. Liver and kidney samples from three cattle and liver samples from two chickens were placed into clean plastic bags and frozen at $-20^{\circ} \mathrm{C}$ for the determination of lead concentrations.

The tissue samples were fixed in $10 \%$ formalin and processed by standard methods for histological analysis in the Anatomic Pathology Department of the Federal University of Pará (Universidade Federal do Pará - UFPA). Subsequently, the tissues were embedded in paraffin, cut into 5 - $\mu \mathrm{m}$-thick slices and stained with hematoxylin-eosin (HE).

For the determination of lead concentrations in tissues, the samples were prepared according to the protocol described by Nomura \& Oliveira (2006). Thereafter, the samples were digested in acid (concentrated nitric acid) in a microwave oven (Multiwave 3000 - Anton Paar), and lead concentration determination was performed by high-resolution atomic absorption spectrometry (Analytik Jena) with atomization in an air-acetylene flame at the Laboratory of Environmental Survey and Analysis, Veterinary
Sciences Center/Santa Catarina State University (Universidade do Estado de Santa Catarina - UDESC).

\section{RESULTS}

The cases of calves with neurological disorders occurred in August and September 2012 on a farm in the municipality of Bom Jesus do Tocantins, in the southeast region of the state of Pará. This farm held 345 Holstein-Zebu crossbred cattle kept in an extensive production system in a Brachiaria brizantha pasture, with water and mineral supplementation provided ad libitum. In a lot of 80 calves, 10 animals became sick, including eight females and two males, of which nine died and one recovered after being removed from the paddock. These calves were the offspring of dairy cows and ranged from two to eight months of age, and they were left overnight in a paddock separated from their mothers so that milking of the mothers could be performed the following day.

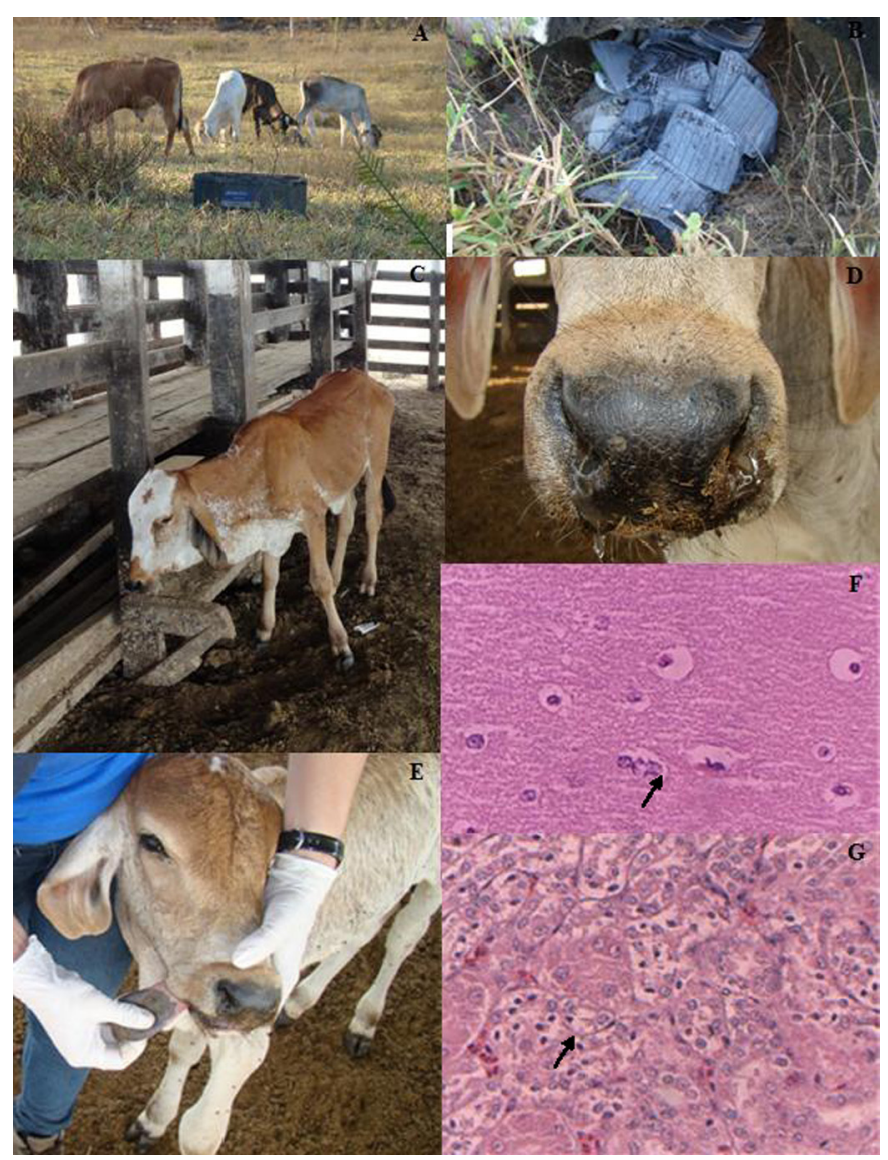

Fig.1. Lead poisoning. (A) Truck battery box observed in the pasture during the inspection of the paddock where the calves were kept. (B) Lead plates removed from the batteries and discarded in the pasture. (C) Eight-month-old female calf with depression and abducted anterior limbs. (D) Two-month-old female calf with a dry snout and serous secretion in the nostrils, and (E) with decreased tongue tone. (F) Histological section of the cerebral cortex of a calf showing astrocytosis and the presence of Alzheimer type II astrocytes (arrow). (G) Histological section of a chicken kidney with observed nuclear pyknosis of tubular epithelial cells (arrow). HE, obj.40x. Bom Jesus do Tocantins, PA. 
Table 1. Lead values in the liver tissue of cattle and chickens, and kidney tissues of cattle poisoned by lead from batteries. Bom Jesus do Tocantins, PA

\begin{tabular}{|c|c|c|c|c|c|c|}
\hline \multirow[t]{2}{*}{ Animals } & \multicolumn{3}{|c|}{ Liver } & \multicolumn{3}{|c|}{ Kidney } \\
\hline & $\begin{array}{c}\text { Lead } \\
(\mathrm{mg} / \mathrm{kg})\end{array}$ & Mean & $\begin{array}{c}\text { Reference } \\
\text { value } \\
(\mathrm{mg} / \mathrm{kg})\end{array}$ & $\begin{array}{c}\text { Lead } \\
(\mathrm{mg} / \mathrm{kg})\end{array}$ & Mean & $\begin{array}{c}\text { Reference } \\
\text { value } \\
(\mathrm{mg} / \mathrm{kg})\end{array}$ \\
\hline Calf 01 & 78.48 & 93.91 & $10-20^{a}$ & 71.32 & 209.76 & $\leq 25^{\mathrm{a}}$ \\
\hline Calf 02 & 66.14 & & & 118.27 & & \\
\hline Calf 03 & 137.12 & & & 439.69 & & \\
\hline Chicken 01 & 65.55 & 105.02 & $\leq 18^{\mathrm{b}}$ & - & - & - \\
\hline Chicken 02 & 144.49 & & & & & \\
\hline
\end{tabular}

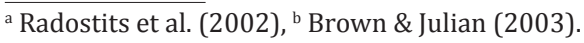

During inspection of the paddock in which the lot of calves was kept, the presence of lead plates derived from five truck batteries with 100 amps was observed. The batteries were used to store energy captured by solar panels, and it was reported by the owner that the lead from some of the plates was used for the production of bullets intended for hunting. However, the owner also reported that when lead was removed from the batteries, fragments fell to the ground in places that the chickens, destined for subsistence, had access to and that the birds had been observed ingesting these fragments.

The clinical signs presented by the calves primarily involved the nervous system and were characterized by apathy, excessive salivation, teeth grinding, proprioceptive disorders, muscle tremors, decreased tongue tone, pushing of the head against objects and blindness. Inappetence, nasal secretion, breathing difficulty and recumbency progressing to death over a mean period of 24 hours after the onset of clinical signs were also observed (Fig.1). No neurological clinical signs were observed in chickens. However, according to reports by the property owner, chickens showed a decrease in oviposition and laid eggs with thin or malformed shells.

There were no significant necropsy findings and no significant histological changes observed in the calves or chickens; however, in one calf mild cortical astrocytosis wasd observed, and in one chicken mild tubular necrosis in kidney (Fig.1). The mean levels of lead in the livers and kidneys of the calves were $93.9 \mathrm{mg} / \mathrm{kg}$ and $209.8 \mathrm{mg} / \mathrm{kg}$, respectively. In the livers of the chickens, the mean lead concentration was $105.02 \mathrm{mg} / \mathrm{kg}$ (Table 1).

\section{DISCUSSION}

In our study, the diagnosis of lead poisoning in animals was based on their history, clinical neurological signs, anatomohistopathological findings and the concentration of lead in tissues. The rate of lead poisoning morbidity, considering the lot of 80 calves, was $12.5 \%(10 / 80)$, and the lethality rate was $90 \%(9 / 10)$. In cases of lead poisoning, morbidity can vary from 10 to $30 \%$, and lethality can reach $100 \%$, depending on the type of treatment given to the animal (Krametter-Froetscher et al. 2007).

In the farm under study, only calves two to eight months old showed clinical signs of lead poisoning, as this was the only lot of animals that had access to the paddock with the batteries. Lead poisoning is most commonly observed in calves up to six months of age, suggesting that this increased susceptibility of young cattle to lead poisoning is due to increased curiosity and behaviors such as licking foreign objects (Blakley 1984, Gava 2001). The neurological clinical signs presented by the calves, including depression, pushing the head against objects, blindness and death, and the absence of macroscopic findings were similar to cases of lead poisoning in cattle reported by Lemos et al. (2004) and Traverso et al. (2004).

The source of lead poisoning in animals at this farm was improperly discarded and mishandled truck batteries, similar to what has been described in the UK, where batteries abandoned in inappropriate places represent a common cause of lead poisoning in cattle and sheep (Payne \& Livesey 2010).

Histopathological examination revealed mild cortical astrocytosis in one animal. According to Summers et al. (1995), this disorder is not commonly described in cattle poisoned by lead; however, it is often reported in dogs poisoned by this element. This result also differs from the findings described by Traverso et al. (2004) in cattle poisoned by lead. The histopathology of these previous cases showed neuronal necrosis, cerebrocortical malacia, gliosis and inclusion bodies in the convoluted tubules of the kidneys. Most likely, the acute clinical outcome in the cases in the present study may have been a contributing factor to the absence of macroscopic and microscopic lesions.

The chickens in this study showed no clinical neurological signs, which may be related to a greater tolerance of birds to lead. However, Mazliah et al. (1989) administered daily doses of lead acetate at $5.0 \mathrm{mg} / \mathrm{kg}$ body weight to chickens and observed that the birds presented neuromuscular symptoms, such as muscle weakness, atrophy and motor nerve degeneration. The decrease in oviposition and the oviposition of eggs with thin or malformed shells, as reported by the owner, may be related to an interference in calcium absorption in the digestive tract of the birds because lead competes with calcium and zinc for absorption and interferes with vitamin D metabolism (IPCS 1995).

The mean concentrations of lead in certain calf tissues were approximately five times higher than normal in the liver and eight times higher than normal in the kidney. In the livers of chickens, the mean concentration of lead was approximately six times higher than normal. According to Radostits et al. (2002), determination of the lead concentration in animal tissues is important for the diagnosis of lead poisoning, and the tissues that should be analyzed include the blood, liver, kidney and muscles. Among these, the kidney is the tissue that will contain the highest concentration of lead, as observed in the present study.

High concentrations of lead in liver and kidney samples from cattle poisoned by lead were also reported in studies by Lemos et al. (2004) and Traverso et al. (2004). In addition, lead concentrations in the liver and kidney of poisoned cattle in Rio Grande do Sul were approximately 6 and 82 times greater than normal, while in Mato Grosso do Sul, the lead concentrations were approximately 2 and 18 times greater than normal, respectively (Lemos et al. 2004, Traverso et al. 2004). 


\section{CONCLUSION}

It can be concluded that the source of the lead that intoxicated the calves and chickens in this study was truck battery plates used on the farm to store energy captured by solar panels, which were within reach of the animals.

Acknowledgements.- The authors would like to thank Conselho Nacional de Desenvolvimento Científico e Tecnológico (CNPq), Fundação Amazônia Paraense de Amparo a Pesquisa (FAPESPA), Pró-Reitoria de Pesquisa e Pós Graduação da Universidade Federal do Pará (PROPESP/UFPA), INCT Informação Genético-Sanitária da Pecuária Brasileira and Coordenação de Aperfeiçoamento de Pessoal de Nível Superior (CAPES) for financial support and scholarships. J.D. Barbosa has a research fellowship from CNPq.

\section{REFERENCES}

Blakley B.R. 1984. A retrospective study of lead poisoning in cattle. Vet. Hum. Toxicol. 26(6):505-507.

Brown T.P. \& Julian R.J. 2003. Other toxins and poisons, p.1133-1159. In: Saif Y.M., Barnes H.J., Fadly A.M., Glisson J.R., McDougald L.R. \& Swayne D.E. (Eds), Diseases of poultry $11^{\text {th }}$ Ed. Blackwell Publishing Company, Iowa, USA. (CD-ROM)

Dirksen G., Gründer H.D. \& Stöber M. 1993. Exame Clínico dos Bovinos. Guanabara Koogan, Rio de Janeiro.

Gava A. 2001. Intoxicação por chumbo, p.55-59. In: Riet-Correa F., Schild A.N., Lemos R.A.A. \& Borges J.R.J. (Eds), Doenças de Ruminantes e Equídeos. Vol.2. $3^{\underline{a}}$ ed. Varela, São Paulo.

Guagnini F.S., Corrêa A.M.R., Colodel E.M., Pescador C.A., Pedroso P.M.O., Moraes R.B. \& Driemeier D. 2005. Intoxicação por chumbo em bovinos em área de treinamento militar. Salão de Iniciação Científica da UFRGS. Porto Alegre, Rio Grande do Sul.

IPCS 1995. Inorganic Lead. Environmental Health Criteria 165, International Programme on Chemical Safety, World Health Organization, Geneva.

Krametter-Froetscher R., Tataruch F., Hauser S., Leschnik M., Url A. \& Baumgartner W. 2007. Toxic effects seen in a herd of beef cattle follow- ing exposure to ash residues contaminated by lead and mercury. Vet. J. 174:99-105.

Lemos R.A.A., Driemeier D., Guimarães E.B., Dutra I.S. \& Barros C.S.L. 2004. Lead poisoning in cattle grazing pasture contaminated by industrial waste. Vet. Hum. Toxicol. 46:326-328.

Liu Z.P. 2003. Lead poisoning combined with cadmium in sheep and horses in the vicinity of non-ferrous metal smelters. Scient. Total Environ. 309:117-126.

Marçal W.S. 2005. Intoxicação por chumbo em gado bovino em zona rural próxima a indústria metalífera. Vet. Notícias 11(1):87-93.

Mazliah J., Barron S., Bental E. \& Reznik I. 1989. The effect of chronic lead intoxication in mature chicken. Avian Dis. 33:566-570.

Mazzeo R.J.R., Clotilde E.M.P., Cappellaro C.E.M., Portugual M.A.S.C. \& Giovanardi A.A. 1984. Ocorrência de saturnismo em equinos no estado de São Paulo. Biológico, SãoPaulo, 50:115-117.

Morgan R.V. 1994. Lead poisoning in small companion animals: an update (1987-1992). Vet. Hum. Toxicol. 38:18-22.

Nomura C.S. \& Oliveira P.V. 2006. Preparação de amostra de fígado bovino e estudo de micro homogeneidade para a determinação de $\mathrm{Cd}$ e $\mathrm{Pb}$ por espectrometria de absorção atômica com atomização eletrotérmica e amostragem direta de sólido. Química Nova 29(2):234-239.

Oskarsson A., Jorhem L., Sundberg J., Nilsson N. \& Albanus L. 1992. Lead poisoning in cattle - transfer of lead to milk. Scient. Total Environ. 111:83-94.

Palacios H., Iribarren I., Olalla M.J. \& Cala V. 2002. Lead poisoning of horses in the vicinity of a battery recycling plant. Scient. Total Environ. 290:81-89.

Payne J. \& Livesey C. 2010. Lead poisoning in cattle and sheep. Farm Anim. Pract. 32:64-69.

Radostits O.M., Gay C.C., Blood D.C. \& Hinchcliff K.W. 2002. Veterinary Clinic: a treatise on the diseases of cattle, sheep, pigs, goats and horses, ninth edition. Guanabara Koogan, Rio de Janeiro, p.507-511.

Summers B.A., Cummings J.F. \& Lahunta A. 1995. Veterinary Neuropathology. Mosby-Year Book, St. Louis.

Traverso S.D., Loretti A.P., Donini M.A. \& Driemeier D. 2004. Lead poisoning in cattle in southern Brazil. Arq. Bras. Med. Vet. Zootec. 56(3):418-421. 